\title{
ANALISA FAKTOR YANG BERHUBUNGAN DENGAN KINERJA PERAWAT DI RUANG RAWAT INAP RUMAH SAKIT UMUM SEMBIRING
}

\author{
Sri Sudewi Pratiwi Sitio \\ Institut Kesehatan Deli Husada, Jalan Besar No 77 Delitua Deli Serdang \\ email : dewisitio08@gmail.com
}

\begin{abstract}
A nurse is someone who has the ability, responsibility and authority to provide nursing care services at various levels of nursing services. Nursing services provided are in the form of nurse performance and must be based on high ability so that performance supports the implementation of tasks in nursing services. The purpose of this study was to determine the dominant factors related to the performance of nurses in the inpatient ward of the Sembiring General Hospital. This type of research is observational analytic with cross sectional approach where the population is all nurses in hospital inpatient rooms. Sembiring General Hospital with a sample of 101 respondents taken using proportional random sampling technique. Based on the research results of leadership variables, performance, work promotion, incentives, working conditions, work relationships, and workload results obtained workload variables that are significantly related to the performance of nurses in the inpatient room. It is recommended to the Head of Sembiring General Hospital to pay more attention to the arrangements of nurses' work shifts, nurses' work rotations, job descriptions in accordance with the competence and timeliness of nurses' entry and return from work. so that in carrying out their work nurses can work effectively.
\end{abstract}

Keywords: Working Conditions, Workload, Performance

\section{PENDAHULUAN}

Suatu layanan kesehatan dalam kegiatan perawatan mempunyai peranan penting dalam menentukan keberhasilan pelayanan kesehatan secara keseluruhan. Salah satu faktor yang mendukung keyakinan di atas ini adalah kenyataan yang dapat dilihat di unit pelayanan kesehatan seperti rumah sakit, dimana tenaga kesehatan yang selama 24 jam harus berada di sisi pasien adalah perawat (Sumiyati, 2006). Berdasarkan Undang-undang Nomor 38 Tahun 2014 Pasal 30 mendefeniskan perawat adalah seseorang yang telah lulus pendidikan tinggi keperawatan, baik didalam maupun diluar negeri yang diakui pemerintah sesuai dengan ketentuan Peraturan Perundangundangan yang sesungguhnya bertindak secara mandiri merawat dengan sifat caring yang bertujuan 
untuk upaya peningkatan kesehatan, mempertahankan kesehatan optimal pasien, pencegahan penyakit dan pemulihan.

Keunggulan suatu rumah sakit sebagai penyedia pelayanan kesehatan sangat bergantung pada kemampuannya dalam upaya penyediaan ketenagaan proporsional sesuai kualifikasi dan kebutuhan untuk mencapai kinerja yang optimal. Kinerja yang optimal dapat diraih jika produkivitas tenaga kesehatan mengalami kemajuan atau peningkatan. Untuk mencapai produktivitas kerja tenaga kesehatan sesuai dengan harapan, maka perlu dilakukan penilaian kinerja yang telah dicapai tenaga kesehatan (Dwi. R, 2015).

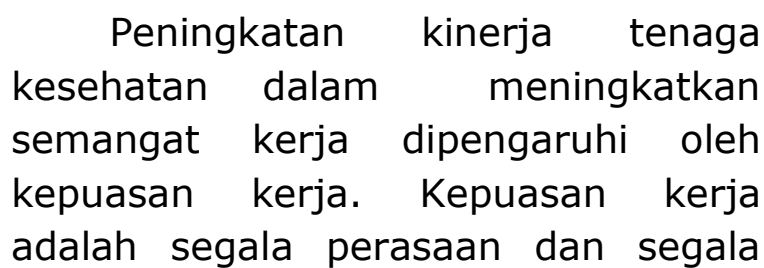
sesuatu di lingkungan kerjanya. Ketidakpuasan tenaga kesehatan berhubungan dengan semangat rendah tenaga kesehatan yang menyebabkan penurunan kinerja (Depkes, 2014). Menurut As'ad (2008) faktor-faktor yang mempengaruhi kinerja perawat adalah karakteristik, motivasi, kemampuan, ketrampilan, persepsi, sikap serta lingkungan.

Adapun yang termasuk dalam karakteristik perawat meliputi umur, pendidikan, tingkat pengetahuan, masa kerja serta status. Masa kerja berpengaruh terhadap kinerja perawat dalam melaksanankan asuhan keperawatan karena semakin lama masa kerja seorang perawat semakin banyak pengalaman yang diperoleh dalam menyelesaikan pekerjaanya sehingga dapat meningkatkan kinerja perawat. Rumah Sakit Umum Sembiring merupakan rumah sakit tipe $B$ pendidikan.

Rumah sakit tersebut merupakan pelayanan kesehatan terhadap masyarakat kabupaten Deli Serdang, dan menjadi rumah sakit rujukan bagi puskesmas-puskesmas yang ada di Kabupaten Deli Serdang. Jumlah perawat diruang rawat inap 136 perawat dari tenaga kesehatan seluruhnya 327. Berdasarkan hasil survey dan wawancara yang diperoleh diketahui hasil sebagai berikut: dilihat dari hak pegawai $50 \%$ merasa sangat tidak puas dengan gaji yang diterima, $50 \%$ tidak merasa puas dalam hal kesempatan memperoleh promosi jabatan oleh rumah sakit, $40 \%$ tidak puas dalam supervisi dan $40 \%$ merasa tidak puas dalam hubungan antar interpersonal di tempat bekerja.

Diihat dari tangung jawab $65 \%$ tidak puas dengan beban kerja yang diterima. Terkait dengan profesionalitas kerja terlihat 35,5\% pegawai mersa dirinya bukanlah orang yang mandiri dalam pekerjaan, 25\% merasa tidak bangga saat 
membicarkan pekerjaannya dengan orang lain. Selain itu, 23,9\% pegawai merasa tidak puas dengan keterampilan kerja yang dimilikinya dan $41,7 \%$ pegawai merasa beban yang dihadapi berpengaruh pada kinerjanya. Untuk tingkat turn over pegawai pada tahun 2014 ada sebanyak 95 pegawai, dan pada tahun 2017 jumlah pegawai telah mengalami perubahan menjadi 75 pegawai. Selain itu, tingkat absensi tertinggi terjadi pada tahun 2016 yaitu sebanyak 320 pegawai, yang absen kerja selama tahun 2016.

Jumlah pegawai yang keluar dan yang paling tertinggi terjadi pada tahun 2017 yaitu sebanyak 25 pegawai, dan pada tahun 2015 pegawai yang masuk sebanyak 28 orang. Tingginya tingkat absensi dan jumlah pegawai yang keluar dapat menjadi indikasi bahwa pegawai merasa kurang termotivasi dan kurang puas dengan pekerjaan yang dilakukan. Tingginya jumlah pegawai yang keluar dapat juga di sebabkan karena instansi ingin melakukan efisiensi biaya, yaitu dengan mengurangi jumlah pegawai sehingga pekerjaan menjadi lebih ramping. Pegawai yang kepuasan kerjanya rendah akan berakibat pada penurunan kinerja secara keseluruhan, yang berpengaruh dalam meningkatkan kualitas pelayanan suatu instansi.

\section{METODE PENELITIAN}

Penelitian ini termasuk dalam penelitian observasional yaitu tidak melakukan perlakuan pada subyek penelitian dalam rangka memberikan gambaran secara lebih jela tentang masalah pada subyek. Jenis penelitian ini adalah Jenis Survei dengan desain Cross Sectional dimana varibel independen dan dependennya dikumpulkan pada saat atau periode yang sama artinya setiap subjek penelitian diobervasi hanya satu kali saja dan dapat diukur menurut keadaan atau status pada saat observasi (Creswell, 2012).

Populasi dalam penelitian ini adalah semua perawat pelaksana yang bertugas di Ruang Rawat Inap Rumah Sakit Umum Sembiring, Kabupaten Deli Serdang, yang berjumlah 136 orang. Sampel yang di ambil adalah Ruang Rawat Inap Rumah Sakit Umum Sembiring pada tahun Kabupaten Deli Serdang sebanyak 101orang.

\section{HASIL DAN PEMBAHASAN}

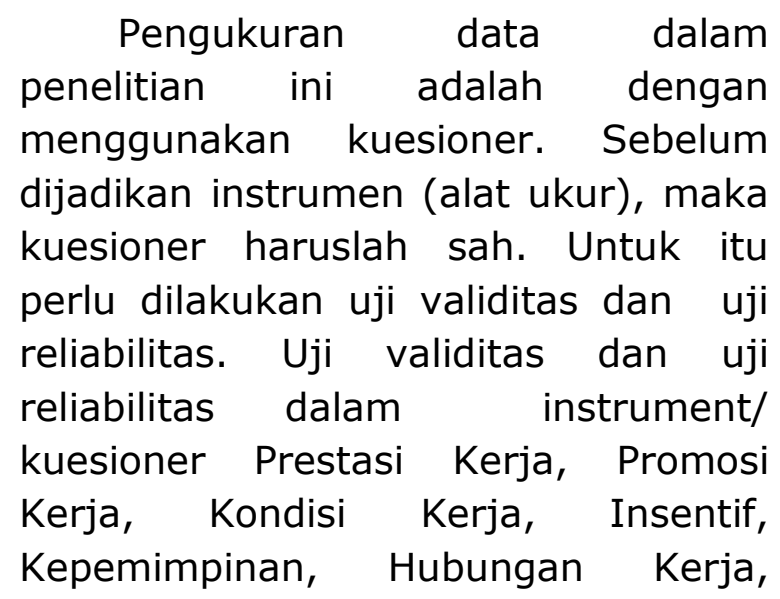


Beban Kerja dan Kinerja Perawat melibatkan masing-masing 67 perawat di Rumah Sakit Umum Sembiring. Uji Reabilitas dilakukan di Rumah Sakit Umum Sembiring kepada 49 orang responden dengan kriteria sampel yang sama dengan nilai Cronbach's Alpa 0,801.

Hasil pengolahan dan analisis data dengan metode analisis univariat, analisis bivariat dan miltivariat. Data identitas responden dianalisis dengan menggunakan tabel distribusi frekuensi. Hasil penelitian yang disajikan pada bab ini didapatkan dari pengolahan dan analisis jawaban kuesioner 101 responden di Ruang Rawat Inap Rumah Sakit Umum Sembiring, Kabupaten Deli Serdang.

Tabel 1. Hubungan Kepemimpinan Dengan Kinerja Perawat di Ruang Rawat Inap Rumah Sakit Umum Sembiring Tahun 2018

\begin{tabular}{|c|c|c|c|c|c|c|c|c|c|}
\hline \multirow{3}{*}{$\begin{array}{l}\text { Kepemimpin } \\
\text { an }\end{array}$} & \multicolumn{4}{|c|}{ Kinerja Perawat } & \multirow{2}{*}{\multicolumn{2}{|c|}{ Total }} & \multirow{3}{*}{ PR } & \multirow{3}{*}{$95 \%$ CI } & \multirow{3}{*}{$\begin{array}{c}\text { p- } \\
\text { value }\end{array}$} \\
\hline & \multicolumn{2}{|c|}{ Baik } & \multicolumn{2}{|c|}{ Buruk } & & & & & \\
\hline & f & $\%$ & $\mathbf{f}$ & $\%$ & f & $\%$ & & & \\
\hline Bai & 28 & 66,7 & 14 & 33,3 & 42 & 41,6 & 1,513 & $1,057-2,165$ & 0,025 \\
\hline Buruk & 26 & 44,1 & 33 & 55,9 & 59 & 58,4 & 1,513 & $1,007-2,100$ & $0,0<0$ \\
\hline
\end{tabular}

Berdasarkan analisis statistik bivariat menunjukkan bahwa kepemimpinan mempunyai pengaruh yang signifikan terhadap kinerja perawat dengan nilai $p$-value 0,025 . Berdasarkan hasil multivariat menunjukkan bahwa kepemimpinan nilai sig $(1,0)$ dengan nilai $\operatorname{Exp}(B)$ 4,182 (CI : 0,031-1,044) dimana pengaruh kepemimpinan tidak bermakna dengan kinerja perawat di Ruang Rawat Inap Rumah Sakit Umum Sembiring.

Tabel 2. Hubungan Prestasi Kerja Dengan Kinerja Perawat di Ruang Rawat Inap Rumah Sakit Umum Sembiring Tahun 2018

\begin{tabular}{|c|c|c|c|c|c|c|c|c|c|}
\hline \multirow{3}{*}{ Prestasi Kerja } & \multicolumn{4}{|c|}{ Kinerja Perawat } & \multirow{2}{*}{\multicolumn{2}{|c|}{ Total }} & \multirow{3}{*}{ PR } & \multirow{3}{*}{$95 \% \mathrm{CI}$} & \multirow{3}{*}{$\begin{array}{c}\text { p- } \\
\text { value }\end{array}$} \\
\hline & \multicolumn{2}{|c|}{ Baik } & \multicolumn{2}{|c|}{ Buruk } & & & & & \\
\hline & $\mathbf{f}$ & $\%$ & $\mathbf{f}$ & $\%$ & $f$ & $\%$ & & & \\
\hline Baik & 24 & 66,7 & 12 & 33,3 & 36 & 35,6 & & & \\
\hline Buruk & 30 & 46,2 & 35 & 53,8 & 65 & 64,4 & 4 & y & 0,04 \\
\hline
\end{tabular}

Berdasarkan analisis statistik bivariat menunjukkan bahwa prestasi kerja mempunyai pengaruh yang signifikan terhadap kinerja perawat dengan nilai p-value 0,048.
Berdasarkan hasil multivariat menunjukkan bahwa prestasi kerja dengan nilai sig sig $(0,967)$ dengan nilai $\operatorname{Exp}(B) 1,065$ (CI : 1,054-1,486) dimana prestasi kerja tidak bermakna 
dengan kinerja perawat di Ruang Rawat Inap Rumah Sakit Umum

Sembiring.

Tabel 3. Hubungan Promosi Kerja Dengan Kinerja Perawat di Ruang Rawat Inap Rumah Sakit Umum Sembiring Tahun 2018

\begin{tabular}{|c|c|c|c|c|c|c|c|c|c|}
\hline \multirow{3}{*}{ Promosi Kerja } & \multicolumn{4}{|c|}{ Kinerja Perawat } & \multirow{2}{*}{\multicolumn{2}{|c|}{$\begin{array}{l}\text { To } \\
\text { tal }\end{array}$}} & \multirow{3}{*}{ PR } & \multirow{3}{*}{$95 \%$ CI } & \multirow{3}{*}{$\begin{array}{c}\text { p- } \\
\text { value }\end{array}$} \\
\hline & \multicolumn{2}{|c|}{ Baik } & \multicolumn{2}{|c|}{ Buruk } & & & & & \\
\hline & $f$ & $\%$ & $\mathbf{f}$ & $\%$ & $f$ & $\%$ & & & \\
\hline Baik & 28 & 68,3 & 13 & 31,7 & 41 & 40,6 & 576 & $103-2$ & 0,0 \\
\hline Buruk & 26 & 43,3 & 34 & 56,7 & 60 & 59,4 & $5 / 6$ & $1,103-2,251$ & 14 \\
\hline
\end{tabular}

Berdasarkan analisis statistik bivariat menunjukkan bahwa promosi kerja mempunyai pengaruh yang signifikan terhadap kinerja perawat dengan nilai p-value 0,014. Berdasarkan hasil multivariat menunjukkan bahwa prestasi kerja dengan nilai sig $(1,0)$ dengan nilai Exp (B) 4,197 (CI: 1,085-2,079) dimana promosi kerja tidak bermakna dengan kinerja perawat di Ruang Rawat Inap Rumah Sakit Umum Sembiring.

Tabel 4. Hubungan Insentif Dengan Kinerja Perawat di Ruang Rawat Inap Rumah Sakit Umum Sembiring Tahun 2018

\begin{tabular}{|c|c|c|c|c|c|c|c|c|c|}
\hline \multirow{3}{*}{ Insentif } & \multicolumn{4}{|c|}{ Kinerja Perawat } & \multirow{2}{*}{\multicolumn{2}{|c|}{ Total }} & \multirow{3}{*}{ PR } & \multirow{3}{*}{$95 \%$ CI } & \multirow{3}{*}{$\begin{array}{c}\text { p- } \\
\text { value }\end{array}$} \\
\hline & \multicolumn{2}{|c|}{ Baik } & \multicolumn{2}{|c|}{ Buruk } & & & & & \\
\hline & $f$ & $\%$ & $f$ & $\%$ & $f$ & $\%$ & & & \\
\hline Baik & 26 & 66,7 & 13 & 33,3 & 39 & 38,6 & 176 & 1 & \\
\hline Buruk & 28 & 45,2 & 34 & 54,8 & 62 & 61,4 & , 4/6 & $1,03 /-2,101$ & 0,035 \\
\hline
\end{tabular}

Berdasarkan analisis statistik bivariat menunjukkan bahwa Insentif mempunyai pengaruh yang signifikan terhadap kinerja perawat dengan nilai p-value 0,035. Berdasarkan hasil multivariat menunjukkan bahwa
Insentif dengan nilai $(1,0)$ dengan nilai Exp (B) 4,212 (CI : 1,116-2,089) dimana Insentif tidak bermakna dengan kinerja perawat di Ruang Rawat Inap Rumah Sakit Umum Sembiring.

Tabel 5. Hubungan Kondisi Kerja Dengan Kinerja Perawat di Ruang Rawat Inap Rumah Sakit Umum Sembiring Tahun 2018

\begin{tabular}{|c|c|c|c|c|c|c|c|c|c|}
\hline \multirow{3}{*}{ Kondisi Kerja } & \multicolumn{4}{|c|}{ Kinerja Perawat } & \multirow{2}{*}{\multicolumn{2}{|c|}{ Total }} & \multirow{3}{*}{ PR } & \multirow{3}{*}{ 95\% CI } & \multirow{3}{*}{$\begin{array}{c}\text { p- } \\
\text { value }\end{array}$} \\
\hline & \multicolumn{2}{|c|}{ Baik } & \multicolumn{2}{|c|}{ Buruk } & & & & & \\
\hline & f & $\%$ & f & $\%$ & f & $\%$ & & & \\
\hline Baik & 27 & 69,2 & 12 & 30,8 & 39 & 38,6 & & & \\
\hline Buruk & 27 & 43,5 & 35 & 56,5 & 62 & 61,4 & S90 & 1,11 & 0,012 \\
\hline
\end{tabular}


Berdasarkan analisis statistik bivariat menunjukkan bahwa kondisi kerja mempunyai pengaruh yang signifikan terhadap kinerja perawat dengan nilai p-value 0,012. Berdasarkan hasil multivariat menunjukkan bahwa kondisi kerja nilai sig $(0,99)$ dengan nilai Exp (B) 1,080 (CI : 1,147-2,692) dimana kondisi kerja tidak bermakna dengan kinerja perawat di Ruang Rawat Inap Rumah Sakit Umum Sembiring.

Tabel 6. Hubungan Kerja Dengan Kinerja Perawat di Ruang Rawat Inap Rumah Sakit Umum Sembiring Tahun 2018

\begin{tabular}{|c|c|c|c|c|c|c|c|c|c|}
\hline \multirow{3}{*}{$\begin{array}{c}\text { Hubungan } \\
\text { Kerja }\end{array}$} & \multicolumn{4}{|c|}{ Kinerja Perawat } & \multirow{2}{*}{\multicolumn{2}{|c|}{ Total }} & \multirow{3}{*}{ PR } & \multirow{3}{*}{$95 \% \mathrm{CI}$} & \multirow{3}{*}{$\begin{array}{c}\text { p- } \\
\text { value }\end{array}$} \\
\hline & \multicolumn{2}{|c|}{ Baik } & \multicolumn{2}{|c|}{ Buruk } & & & & & \\
\hline & $f$ & $\%$ & $\mathbf{f}$ & $\%$ & $\mathbf{f}$ & $\%$ & & & \\
\hline Baik & 27 & 67,5 & 13 & 32,5 & 40 & 39,6 & & & \\
\hline Buruk & 27 & 32,6 & 34 & 55,7 & 61 & 60,4 & & & \\
\hline
\end{tabular}

Berdasarkan analisis statistik bivariat menunjukkan bahwa hubungan kerja mempunyai pengaruh yang signifikan terhadap kinerja perawat dengan nilai $\mathrm{p}$-value 0,022 . Berdasarkan hasil multivariat menunjukkan bahwa hubungan kerja dengan nilai sig $(0,99)$ dengan nilai Exp (B) 1,095 (CI : 1,169-3,295) dimana hubungan kerja tidak bermakna dengan kinerja perawat di Ruang Rawat Inap Rumah Sakit Umum Sembiring.

Tabel 7. Hubungan Beban Kerja Dengan Kinerja Perawat di Ruang Rawat Inap Rumah Sakit Umum Sembiring Tahun 2018

\begin{tabular}{|c|c|c|c|c|c|c|c|c|c|}
\hline \multirow{3}{*}{ Beban Kerja } & \multicolumn{4}{|c|}{ Kinerja Perawat } & \multirow{2}{*}{\multicolumn{2}{|c|}{ Total }} & \multirow{3}{*}{ PR } & \multirow{3}{*}{$95 \%$ CI } & \multirow{3}{*}{$\begin{array}{c}\text { p- } \\
\text { value }\end{array}$} \\
\hline & \multicolumn{2}{|c|}{ Baik } & \multicolumn{2}{|c|}{ Buruk } & & & & & \\
\hline & $\mathbf{f}$ & $\%$ & $\mathbf{f}$ & $\%$ & $\mathbf{f}$ & $\%$ & & & \\
\hline Rendah & 29 & 70,7 & 12 & 29,3 & 41 & 40,6 & & & \\
\hline Tinggi & 25 & 41,7 & 35 & 58,3 & 60 & 59,4 & 1,698 & $1,186-2,429$ & 0,004 \\
\hline
\end{tabular}

Berdasarkan analisis statistik bivariat menunjukkan bahwa beban kerja mempunyai pengaruh yang signifikan terhadap kinerja perawat dengan nilai p-value 0,004. Berdasarkan hasil multivariat menunjukkan bahwa beban kerja dengan nilai sig $(0,020)$ dengan nilai
Exp (B) 2,939 (CI : 1,185- 7,291) dimana beban kerja memiliki hubungan yang bermakna dengan kinerja perawat di Ruang Rawat Inap Rumah Sakit Umum Sembiring.

\section{KESIMPULAN}


Diketahui dari 101 perawat di Ruang Rawat Inap Rumah Sakit Umum Sembiring berdasarkan jenis kelamin bahwa distribusi terbanyak adalah perempuan yaitu $55,4 \%$, dengan tingkat pendidikan terbanyak pendidikan S1/Ners sebanyak $47,5 \%$ dengan rata-rata usia perawat yakni 29,91 dengan usia minimum 22 tahun dan usia maksimum 45 tahun. Berdasarkan lama bekerja dimana rata-rata lama bekerja responden adalah 2,74 dengan lama bekerja minimum 1 tahun dan lama bekerja maksimum 8 tahun. Berdasarkan analisis multivariat diketahui ada hubungan yang signifikan antara beban kerja dengan kinerja perawat di ruang rawat inap Rumah Sakit Umum Sembiring dengan nilai p-value 0,004.

\section{SARAN}

1. Diharapkan kepada Pimpinan Rumah Sakit Umum Sembiring agar lebih memperhatikan pengaturan jadwal shift kerja perawat, rotasi kerja perawat, pembagian job deskripsi kerja yang sesuai kompetensi dan ketepatan waktu masuk dan pulang kerja perawat sehingga dalam melaksanakan pekerjaannya perawat dapat bekerja secara efektif sehingga perawat menjadi lebih bertanggung jawab atas tugas yang diberikan sesuai kewenangannya.
2. Diharapkan kepada Pimpinan Rumah Sakit Umum Sembiring untuk lebih menegakkan peraturan kerja dengan pemberian reward dan punishmend terhadap perawat dalam melaksanakan kerjanya sehingga setiap perawat merasa adanya pemerataan keadilan dalam bekerja sehingga diharapkan perawat lebih menghargai waktu dan perannya dalam pelaksanaan asuhan keperawatan di ruang rawat inap Rumah Sakit Umum Sembiring.

\section{DAFTAR PUSTAKA}

As'ad, M. (2008). Seri Ilmu Sumber Daya Manusia:Psikologi industri. $\left(4^{\text {th }}\right.$ ed). Yogyakarta: Liberty.

Creswell, J. 2012. Research Design Pendekatan Kualitatif, Kuantitatif, dan Mixed. Yogyakarta: Pustaka Pelajar.

Departemen Kesehatan R.I. 2004. Standar Pelayanan Rumah Sakit. Cetakan Kedua. Jakarta.

Departemen Kesehatan R.I. 2014. Pusat Data dan Informasi. Jakarta Selatan.

Dwi, R. 2005. Hubungan Antara Stres Kerja Dengan Produktivitas Kerja di Bagian Linting Rokok PT Gentong Gotri Semarang. Skripsi Fakultas Ilmu Keolahragaan Universitas Negeri Semarang. 
Sitio, Analisa Faktor Yang Berhubungan ...

Sumiyati, A. 2006. Analisa FaktorFaktor Yang Berhubungan Dengan Kinerja Kepala Ruang Rawat Inap di Rumah Sakit dr. Karyadi. Semarang: UNDIP.

Undang-undang Nomor 38 Tahun 2014 Pasal 30 Tentang Keperawatan 